\title{
Management Ecosystems Restoration Plans for Coastal Villages: Case Study Gresik and Malang Regency, East Java Province, Indonesia
}

\author{
Rudianto \\ Faculty of Fisheries and Marine Science \\ Brawijaya University \\ Edi susilo \\ Faculty of Fisheries and Marine Science \\ Brawijaya University \\ Supriyatna \\ Faculty of Fisheries and Marine Science \\ Brawijaya University
}

\begin{abstract}
The Villages on the coastal region are currently experiencing severe environmental damage caused by human activities and natural processes. Thus, it required a solution to solve the problem in coastal areas. The coastal area is a unique area and with the presence of mangrove forests to absorb carbon in large enough quantities. However, due to mangrove ecosystems and other ecosystems damaged, mangrove cannot be optimal to absorb carbon. Therefore, research is needed to determine what the best solution to manage ecosystem coastal areas towards restoration. The purpose of this study is to make an ecosystem restoration plan for coastal villages to improve the ability of mangroves to absorb carbon. Such plan will use the village government as a technical guidance together with local people to restore degraded mangrove. Besides, the second objective to be achieved is to develop appropriate institutional plan for deploying the coastal ecosystem restoration. The method used is using Partial Least Square (PLS). PLS regression is a recent technique that generalizes and combines features from principal component analysis and multiple regression. Analytical Hierarchy Process (AHP) which is used to build the institutional model that corresponds to the characteristics of coastal communities to conduct ecosystem restoration plan. The results of this research is to produce findings about the ecosystem restoration plan for coastal village and the local institution that is responsible to carry out ecosystem restoration plan .
\end{abstract}

Key words: Coastal damage, Restoration ecosystem plans for coastal villages, Local institution.

\section{INTRODUCTION}

The coastal area is an area that stores high biological resources, as well as an artificial ecosystem that provides a wide range of environmental services, such as the port area, transportation, industrial zones, tourisms, settlements, ponds and waste dumps (Dahuri et.al, 1996). Potential and advantages of coastal and marine resources Indonesia can be described as follows: that the inland waters, the archipelago waters, territorial sea and has a length of 12 miles. Exclusive Economic Zone has a length of 200 miles from the baselines. The potential of biological resources with a high level of biodiversity that has a high economic value such as: the potential for large pelagic fish amounted to 1.16 million tons, small pelagic amounted to 3.6 
million tonnes, 1.36 million tonnes of demersal fish, shrimp penaid 0.094 million tonnes , 0.004 million tons of lobster, squid 0.028 million tons, and reef fish consumption of 0.14 million tons. The catch is obtained as much as 5.12 million tons per year, or approximately $80 \%$ of the sustainable potential (Richardson, 2008 in Dahuri 2010). Another potential includes: the potential marine aquaculture, brackish aquaculture potential. The potential of coastal and marine areas will encourage the economic growth rate is high both local and regional economies. In order to preserve the potential of fisheries, coastal regions have a strategic role. This is because the coastal area is the process of spawning ground, nursery ground and feeding area ground. If the conditions of both the area of coastal fishery potential can be assured of sustainability. However, if the damaged coastal areas, it will threaten the existence of fishery potential. Ironically coastal areas is currently experiencing degradation of almost $75 \%$ in all coastal areas in Indonesia. Rudianto (2014) has developed a strategy of integrated management of the coastal ecosystem restoration to produce research that treating damaged coastal ecosystems should be addressed first mangrove forests, coral reefs, estuaries and sea grass area. Results were then followed by Rudianto (2015) by arranging the institutional model based on coastal "good governance" for application management strategy. So that the research can be operational and be used as guidance by the local government, the research was continued to determine the extent to which the models that have been developed can be used by the Government of Gresik and Malang Regency Government. Therefore, it was necessary to dialogue in group discussion forum especially with the stakeholders involved.

Based on the conceptual background above, the objective of this study is focussing on preparation of ecosystem restoration plan for coastal villages to improve the ability of mangrove to absorb carbon. Besides, the second objective to be achieved is to develop appropriate institutional plan for deploying the coastal ecosystem restoration. To describe these objectives, the approach used refers to the results of Rudianto (2014) which states there are six (6) objectives to be implemented in terms of restoration activities in degraded coastal area. The sixth of these strategies include: Objective 1: To Improve restoration management of mangrove, estuaries, coral reef and sea grass; Objective 2: To increase the resilience of coastal areas against the threat of natural disasters, and reduce conflicts in coastal areas; Objective 3: To preserve coastal ecosystems based on community participation; Objective 4: To Increase financing sources derived from the government or non-government; Objective 5: To enhance institutional capacity and to improve the quality of human resources; Objective 6: To improve the competitiveness of coastal areas by increasing value-added products to facilitate master plan of economic development acceleration and expansion of Indonesia programs. The sixth objective above, then it is described in the management of ecosystem restoration plans for coastal villages. The management plan includes the planning, implementing, monitoring and evaluation. In order to achieve the effectiveness of the program plan, it is required institutional aspects that will spearhead the implementation of the restoration.

Institutional characteristics and properties are very complex. No matter how good a restoration system that has been built, but if institutions do not have the ability to run a restoration system that has been built, then it will not go well. An institution is a complex of rules and the role of social roles. Thus, the institution has a cultural and structural aspects regarding in terms of the structural form of various social roles (Tony, et al 2004). This is in line with the opinion of Syahyuti (2003) that the institution aspects includes social behavior, where the core study is about the value, the norm custom, mores, folkways, usage, beliefs, morals, ideas, ideas, doctrines, wants, needs, orientation and others. Fitriansah (2012) states that the key to successful handling of damage to coastal areas emerging from the consciousness inherent in society. This indicates that environmental management is done by 
the community more effectively and sustainable. The success of restoration of coastal villages is determined by several things, namely: first, transparent delivery of information from government to the community related with what will be done to overcome the damage to the ecosystem of coastal villages. Second, public participation and private sector are as actors to participate with the government to fix the damage to the coast. This participation should be driven by the government in real terms, and do not mean just for the sake of politics. The village government is encouraging public participation to establish a forum involving all existing stakeholders in the coastal village.

\section{MATERIALS AND METHODS}

The location of this research is in the village of Tambakrejo, and Gajahrejo village in Malang regency and Tanjung Widoro and Banyu Urip village in Gresik regency. Both districts were chosen because they represent a region experiencing severe ecosystem damage in East Java province.

The basis of selecting the two regencies was considered as follows: (a) the level of damage to ecosystems is particularly serious in both regencies with an estimated economic growth rate is very high, but very poor ecological conditions and the level of degradation that occurs quite severe; (b) Each local district has excellent potential as beaches with the blue spring baby tuna and Tuna and skipjack found in Malang regency. While the potential winning in Gresik regency is green mussel (perna viridis). Nevertheless, both districts have limitations in the development of quality products including in marketing; (c) Both regencies have an important position in the development context of East Java province.

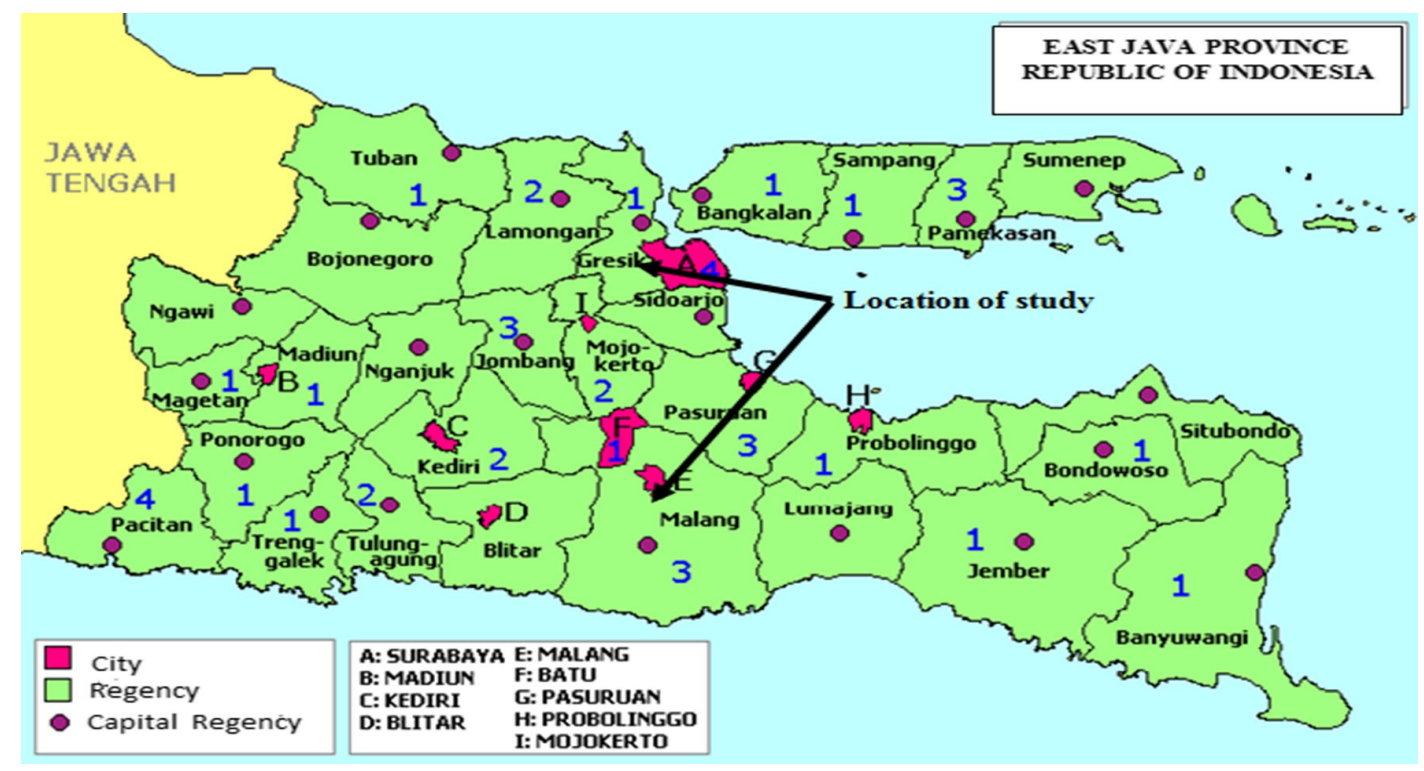

The method will be used to achieve the research objectives using descriptive method with qualitative approach. The focus of research is on developing a plan for ecosystem restoration with a management approach that is at the planning, implementation, monitoring and evaluation stage. This study uses a combination of research. They are descriptive, participatory and exploratory research. The meaning of descriptive research is a method to assess and solve problems and provide interpretation of the facts that exist today. Participatory research is a research method that gives an opportunity to the respondents in the decision making process to resolve the issue of research. While exploratory research is a research method to assess and reveal something of the field as an invention that can be used to develop and draw conclusions 
(Nazir,1988). Therefore, It is needed to identify a conceptual and operational framework. The conceptual framework is a description that explains the concepts of what is contained within the theoretical assumptions that will be used to abstract the elements contained in the phenomenon to be studied and how the relationship between these concepts. While the operational framework is an explanation of what variables are derived from the concepts selected and how the relationship between these variables, as well as what things are used as indicators to measure the variables concerned.

\section{Conceptual Framework includes:}

1. Biophysical-ecology aspects is consisted of inventorying coastal region ecosystem that includes: land cover coverage, diversity of vegetation types, land suitability and usage, the data potential of coastal resources, the level of damage to the ecosystem, the recovery effort;

2. Socio-economic aspects is consisted of focus research on fishing communities located in the region of coastal areas. Characteristics of socio-economic conditions of coastal communities, attitudes, values, norms, behaviour, customs as forming worldview coastal communities against the use, protection and restoration of coastal resources. The size of the welfare (family income) fishing, the level of dependency families, problems encounter, the level of dependency families, aspiration (hope) the fishing community, the views, the preference for ecosystem restoration.

3. The relationship utilization of coastal ecosystems aspect is consisted of how government, community and private sector have access to coastal ecosystems, types of conflict, how the utilization of coastal resources (rational and irrational), form relationships relational utilization of coastal resources, forms of access to coastal communities utilize resources coastal resources and forms of utilization. The measures are necessary mainly related degree of dependence on coastal resources, access and recovery program (restoration).

4. Biodiversity aspect is consisted of the diversity among living organisms from all sources including terrestrial, marine and other aquatic ecosystems and the ecological complexes that are part of its diversity, including diversity of species, between species and of ecosystems. Biodiversity can also be interpreted as a form of life, its ecological role and diversity of germplasm as refer to Act No. 5 of 1994 Article 2 on biodiversity. Biodiversity in this study focused only on flora alone.

5. The resources of life aspect is consisted of genetic resources, organisms, populations, or other biotic component of ecosystems with the benefits or actual or potential value for humanity.

6. The control of coastal land aspect is consisted of a number of coastal land area held by the community, in the form of property rights, lease or pledge. The amount of encouragement to maintain control of the coastal lands shows the dependence of coastal communities on arable land.

7. Typology aspect of coastal communities is characteristic of coastal communities with an interest towards ecosystem restoration activities. To the knowledge of the culture of coastal communities is defined by the level of public attitudes towards nature conservation efforts and the level of dependence on coastal land.

\section{Operational framework includes}

1. The coastal communities are coastal communities living region are grouped into: (a). fishermen fishing (the crew and the owner); (b). farmers / cultivators; (c). processing of marine products; and (d). merchant marine. 
2. The control of coastal land is measured based on the wide use, including coastal land used for fishing and non fishing effort.

3. The area of coastal land ownership is the total land area occupied by coastal communities, the private sector and government in the form of coastal land. Size on the narrowness of tenure by the coastal communities is indicating the size of the driving force to maintain its coastal land. The assumptions used for the coastal land area is 0.7 ha /community as the standard relative land area of coastal community efforts to meet the needs decent.

4. Integrated restoration effort is the effort made jointly between the government, the public and the private sector to restore the condition of damaged ecosystems back to its original state through a variety of activities.

To analyze the institutions that will implement a plan for ecosystem restoration in the coastal village used Partial Least Square (PLS), and Analytical Hierarchy Process (AHP). PLS is used to understand the degree of influence of one variable to another variable. PLS can analyze constructs formed with indicators reflexive and formative indicators. Indicators reflexive view (mathematically) indicator variable as if it were influenced by factors (latent variables) are the same. This resulted in the event of a change of one indicator will result in changes in other indicators in the same direction. While looking formative indicators (mathematically) indicators as if the variables that affect the latent variables.

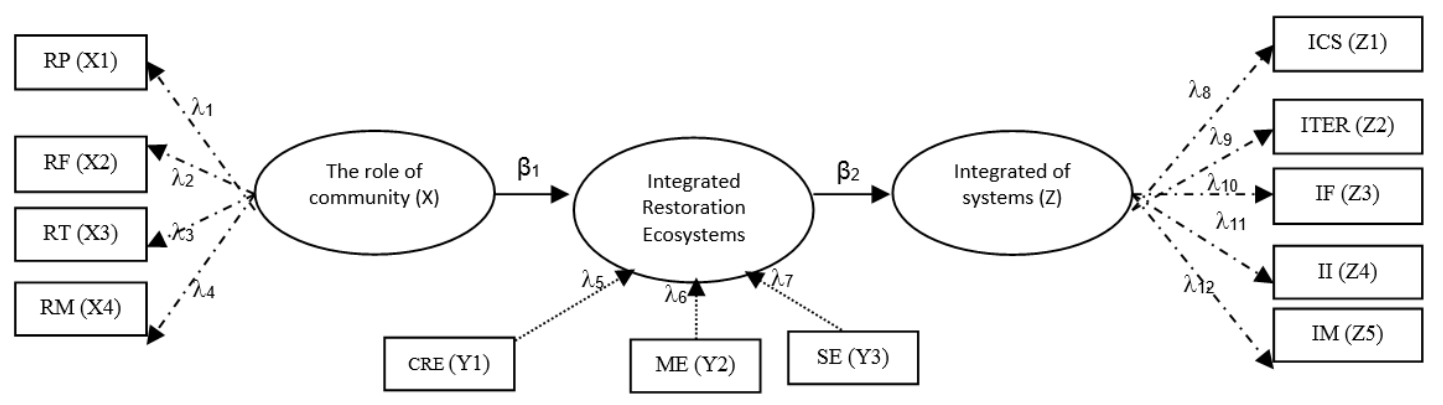

Figure 2: Conceptual Structural Model

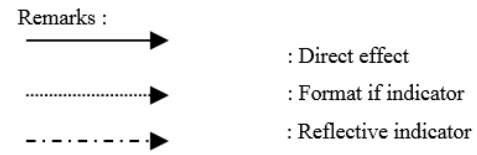

AHP is a framework to take decisions effectively on complex problems by simplifying and accelerating the decision-making process into its parts. Then, arrange the parts in a hierarchical arrangement, as well as giving a numerical value to the consideration to synthesize and to define a variable which has the highest priority. AHP helps solve complex problems with the structure of the hierarchy of criteria from the parties concerned. The result is done by pulling the various considerations in order to develop a weight or priority. This method also combines the strength of feeling and logic is concerned on various issues. Then it was synthesized various diverse considerations. The results correspond to forecasts of researchers intuitively and in line with those presented in the judgment that has been made. (Saaty,1986). In this study, the method of analysis using AHP is conducted as a follow up of the hierarchy ISM formed. From the analysis of AHP, the weights is obtained priorities and alternatives that is illustrating the synergy of government, private sector, and local communities. AHP analysis process is carried out with the help of Expert Choice 11.0 software. 


\section{RESULTS AND DISCUSSION}

The data collected in the field will be described in further detail. The gathered data is then selected and screened adjusted to focus the research. The data has been collected, and then do the editing, coding and tabulation. Continuous process of data reduction is done for ease of use and simplified. Data that has been reduced, then presented to be organized to get the picture clearly and lead to a focus of study. Data will be analyzed and searched the relationship and its meaning and set forth in the form of tentative conclusions.

Existing condition in the coastal area before ecosystem restoration plans for coastal villages program is implemented that it must first be inventoried exploration problems that occur in coastal areas. Table 1 below is illustrated the perception of each stakeholders in terms of six related objectives as stated Rudianto (2014).

Table 1: Characteristics of respondents both in Gresik and Malang regency related with 6 (six) objectives to restore degraded environment

\begin{tabular}{|c|c|c|}
\hline No & Perception of Community & Perception of Government \\
\hline 1. & $\begin{array}{l}\text { Related to the first objective to improve the } \\
\text { management of mangrove ecosystems, coral } \\
\text { reefs, estuaries and seagrass beds, } 73.3 \% \text { of } \\
\text { people believe that the damage to } \\
\text { ecosystems caused by human activity, } \\
\text { especially the land conversion. } 46.7 \% \text { of } \\
\text { people agree needs to be done restoration } \\
\text { program and they think that it should be } \\
\text { done by the village government through the } \\
\text { preparation of a master plan. Besides, } 60 \% \\
\text { of people expect, they are included in the } \\
\text { process of restoration of coastal } \\
\text { management. }\end{array}$ & $\begin{array}{l}\text { Related to the first objective to improve the management } \\
\text { of mangrove ecosystems, coral reefs, estuaries and } \\
\text { seagrass beds, } 42,1 \% \text { of village government believe that } \\
\text { the damage to ecosystems caused by human activity, } \\
\text { especially the land conversion. } 52,6 \% \text {, the village } \\
\text { government agree to restore coastal ecosystem. Therefore, } \\
\text { the village government hope to preprare masterplan and } \\
\text { to allocate in village fund. } 100 \% \text { of the village } \\
\text { government agree to invite people participation in coastal } \\
\text { restoration and they need provincial government } \\
\text { encourage local people participation. }\end{array}$ \\
\hline 2. & $\begin{array}{l}\text { Related to the second objective to increase } \\
\text { resilience of coastal area toward natural } \\
\text { disasters and to reduce social conflict. } 60 \% \\
\text { of people agree that government should } \\
\text { build a forum as bridge between community } \\
\text { and government. Membership of forum is } \\
\text { consisted of represent from community, } \\
\text { private and government. }\end{array}$ & $\begin{array}{l}\text { Related to the second objective to increase resilience of } \\
\text { coastal area toward natural disasters and to reduce social } \\
\text { conflict, } 78,9 \% \text { of the village governments agree to build } \\
\text { a forum consisted of reperesentative of local people, } \\
\text { private sector and the village government. }\end{array}$ \\
\hline 3. & $\begin{array}{l}\text { Related to the third objective to preserve } \\
\text { coastal ecosystems gradually and sustainable } \\
\text { based on the community, } 66,7 \% \text { of } \\
\text { community agree to work together with } \\
\text { government to plant mangrove. } 66.7 \% \\
\text { people agreed to have the awareness to } \\
\text { preserve coastal ecosystems with the } \\
\text { government, but they do not know how to do } \\
\text { coastal restoration. In addition, } 60 \% \text { of } \\
\text { people do not agree, if the government } \\
\text { makes the reclamation program for use as a } \\
\text { residential area or industry. } 67.7 \% \text { of the } \\
\text { public believes the government needs to } \\
\text { establish conservation areas to prevent } \\
\text { damage to mangrove forests. }\end{array}$ & $\begin{array}{l}\text { Related to the third objective to preserve coastal } \\
\text { ecosystems gradually and sustainable based on the } \\
\text { community, } 78,9 \% \text { of the village government agree to } \\
\text { work together with community because of government } \\
\text { limitation. The problems faced that the village } \\
\text { government do not have guidance to do restoration. } 73,7 \\
\% \text { of the village government agree that they are still need } \\
\text { supporting finance from provincial and regency } \\
\text { government. }\end{array}$ \\
\hline 4. & $\begin{array}{l}\text { Associated with the fourth goal to increase } \\
\text { financing resources both from government } \\
\text { resources or non-government, } 40 \% \text { of people } \\
\text { believe that the allocation of village funds }\end{array}$ & $\begin{array}{l}\text { Associated with the fourth goal to increase financing } \\
\text { resources both from government resources or non- } \\
\text { government. the village government agree to finance } \\
\text { coastal restoration use allocated village fund. Beside, the }\end{array}$ \\
\hline
\end{tabular}


can not be used for restoration efforts, but the provincial government and local governments should be able to disburse funds for restoration. $53.3 \%$ of people agree to conduct mutual cooperation for coastal restoration. So far $33.3 \%$ of the public agree that the village government has never present a program to prevent erosion and sedimentation.

5. Associated with his fifth goal of which is to increase the quality of human resources both at the institutional capacity of formal and non-formal, $83.3 \%$ of people agree, especially to provide clarity on the task of handling the public representative institutions, private sector and government.

6. Associated with the sixth goal to improve the competitiveness of coastal areas to increase the added value, $100 \%$ of people agree when implementing the restoration program noticed an increase in employment programs, including community can increase production, productivity, innovation and creativity area. village government hope that private sectors are also allocate Corporate Social Responsibility (CSR) for coastal restoration.
Associated with his fifth goal of which is to increase the quality of human resources both at the institutional capacity of formal and non-formal, $89.3 \%$ of the village government agree that the forum build by the head of village will help overcome the degraded coastal ecosystems. The $93 \%$ of village government agrees to create tansparancies to their people related the restoration program not only in the scope of substance of restoration, but in the scope of using money.

Associated with the sixth goal to improve the competitiveness of coastal areas separately to increase the added value, $84,2 \%$ of the village government agree to increase job opportunity for local people including increasing income.

As a guideline for preparing ecosystem restoration plans for coastal villages, it is structured as a first step before the restoration plans drawn up. Therefore, table below is shown as follows:

Table 2: Identification Priority Areas and Ways

\begin{tabular}{|l|l|}
\hline \multicolumn{1}{|c|}{ Priority Areas } & \multicolumn{1}{c|}{ Ways } \\
\hline Regulations and practices Fisheries & $\begin{array}{l}\text { Law, licensing, supervision, health and safety, } \\
\text { education and training }\end{array}$ \\
\hline $\begin{array}{l}\text { Conservation of coastal and marine (including MPA- } \\
\text { Marine Protected areas and wetlands) program and } \\
\text { public awareness }\end{array}$ & Management, and the benefits to society \\
\hline Integrated Coastal Zone Management & $\begin{array}{l}\text { Establish and improve the planning and management } \\
\text { of institutions (particularly urban, industrial and } \\
\text { tourism-related) }\end{array}$ \\
\hline Control of effluent and pollution control & $\begin{array}{l}\text { Improving local sewage services, sewage systems, } \\
\text { industrial and agricultural waste control; international } \\
\text { action on marine waste, litter and illegal dumping; } \\
\text { management of oil spills; protection against invasive } \\
\text { species }\end{array}$ \\
\hline Coastal Protections & $\begin{array}{l}\text { Vulnerability assessment, adaptive planning of land } \\
\text { use, the maintenance of the coastline; scheme 'Blue } \\
\text { Flag'participatory }\end{array}$ \\
\hline Cooperation between sectors & $\begin{array}{l}\text { Consultation and engagement between stakeholders, } \\
\text { locally, at the catchment scale, national and } \\
\text { international }\end{array}$ \\
\hline Information System, Monitoring, R\&D & $\begin{array}{l}\text { Checking the field and remote sensing techniques, } \\
\text { standards for monitoring, establish performance } \\
\text { indicators, improving the evidence base including } \\
\text { public reporting, financing }\end{array}$ \\
\hline $\begin{array}{l}\text { Operational Capacity and Human Resources } \\
\text { Develop professional resources, technical and } \\
\text { managerial; equipment and physical infrastructure } \\
\text { investment and maintenance }\end{array}$ \\
\hline
\end{tabular}


PLS operational results can be generated as follows: Based on the test results of the validity of research instruments that an instrument is said to be valid if the correlation coefficient more than 0.30 with alpha (standard error) 0.05 (Sugiyono, 2010). Here are the results of testing of convergent validity outer model as seen table 3 below.

Table 3. Testing of Convergent Validity Outer Mode in Gresik regency

\begin{tabular}{|l|l|c|c|c|}
\hline \multicolumn{1}{|c|}{ Variables } & \multicolumn{1}{|c|}{ Indicators } & Code & Outer loading & T-static \\
\hline \multirow{4}{*}{$\begin{array}{l}\text { The role of } \\
\text { community (X) }\end{array}$} & Role in the form of power & RP (X1) & 0.763 & 13.742 \\
\cline { 2 - 5 } & Role in the form of fees & RF (X2) & 0.811 & 16.435 \\
\cline { 2 - 5 } & Role in the form of thought & RT (X3) & 0.851 & 22.388 \\
\cline { 2 - 5 } & Role in the form of material & RM (X4) & 0.631 & 6.806 \\
\hline \multirow{2}{*}{$\begin{array}{l}\text { Integrated of } \\
\text { restoration } \\
\text { Ecosystem (Y) }\end{array}$} & Coral reef ecosystem & CRE (Y1) & 0.933 & 26.792 \\
\cline { 2 - 5 } & Mangrove ecosystem & ME (Y2) & 0.946 & 32.632 \\
\cline { 2 - 5 } & Seagrass ecosystem & SE (Y3) & 0.296 & 2.288 \\
\hline \multirow{3}{*}{$\begin{array}{l}\text { Integrated of } \\
\text { Systems (Z) }\end{array}$} & $\begin{array}{l}\text { Integrated of coastal spatial } \\
\text { The integration of }\end{array}$ & ICS (Z1) & 0.795 & 20.699 \\
\cline { 2 - 5 } & The integration of funding & IF (Z3) & 0.689 & 7.528 \\
\cline { 2 - 5 } & The integration of institution & II (Z4) & 0.757 & 7.425 \\
\cline { 2 - 5 } & The integration of management & IM (Z5) & 0.750 & 9.533 \\
\hline
\end{tabular}

After the validity, reliability, and consistency of the constituent indicators of latent variables (outer model) are met, the next step is to conduct testing on inner structural model. Testing inner model (structural model) essentially testing the hypothesis. Hypothesis testing is done by $t$ test (T-statistic) at each track direct effect partially. Based on the results of the analysis by using statistical software SmartPLS, the test results Inner Model Gresik regency as follows: The following structural outer model as follows:
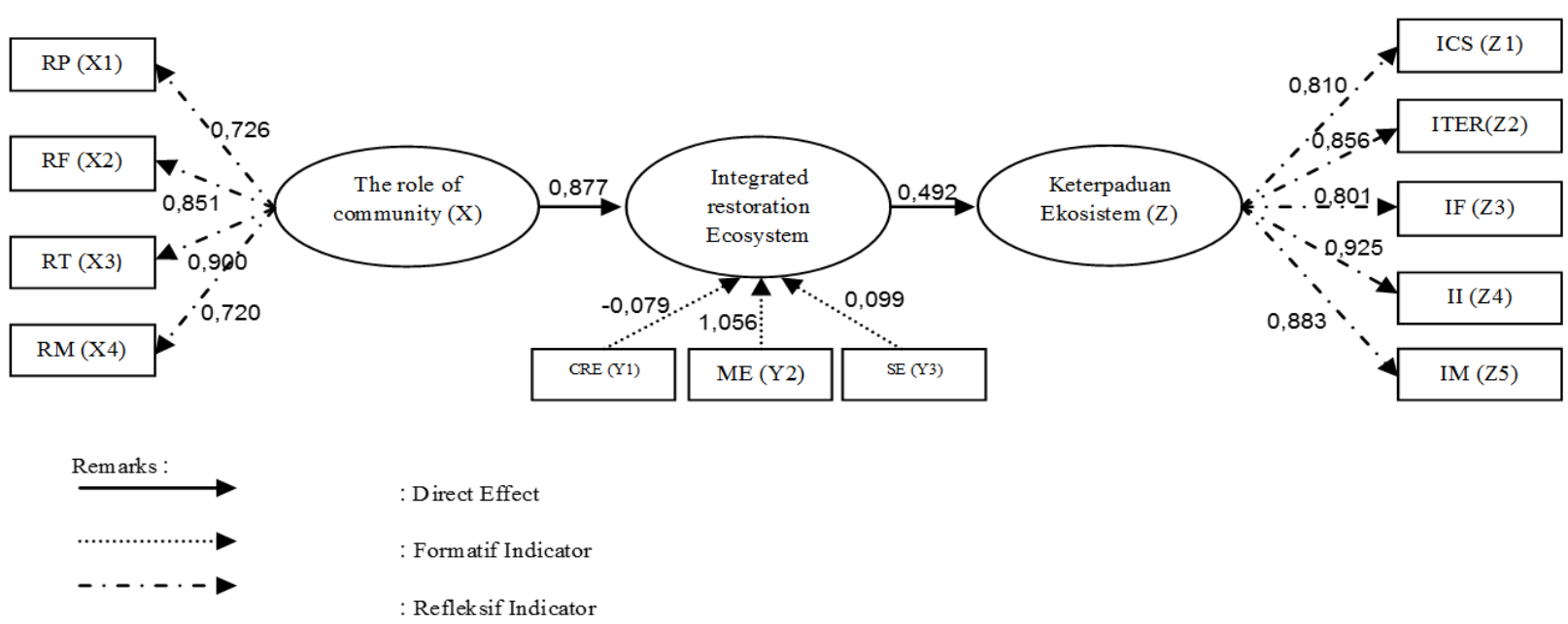

Figure 3: Structural Conceptual Model for Gresik Regency

The same way done also in the district of Malang with the structural model as follows: 


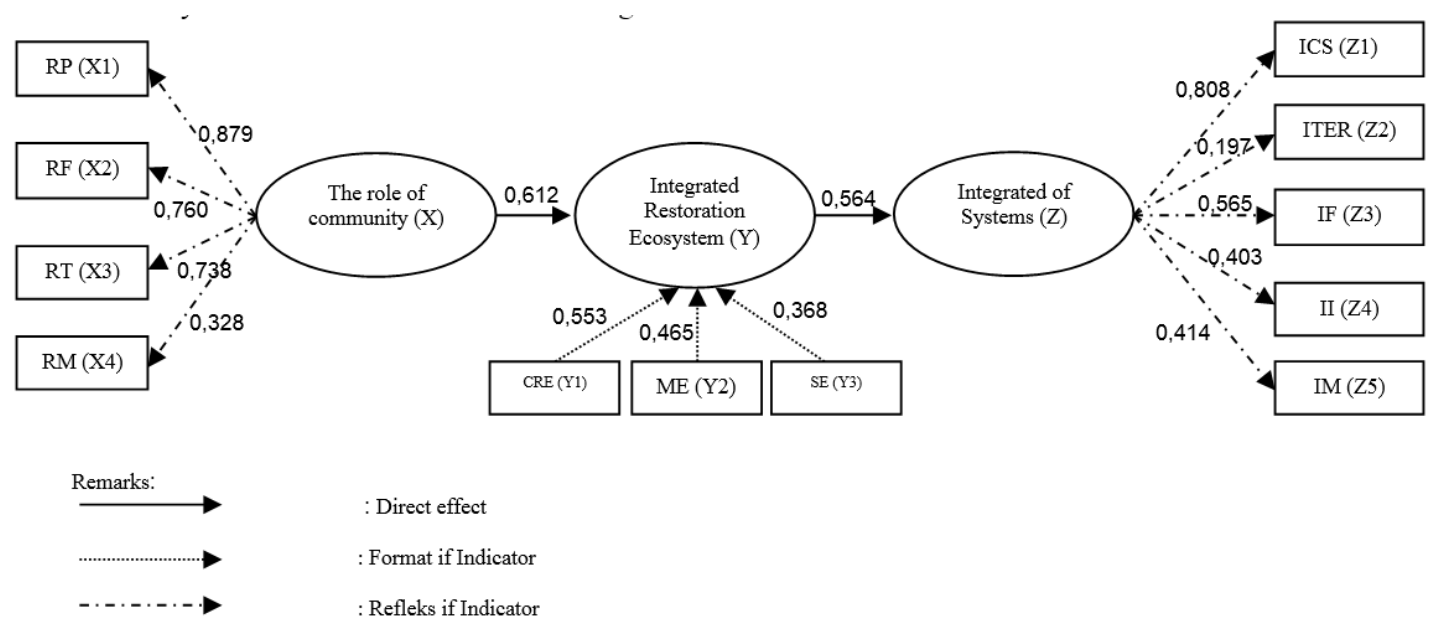

Figure 4: Structural Conceptual Model For Malang Regency

The amount of total variable influence can also be seen in the following figure both Gresik and Malang regency

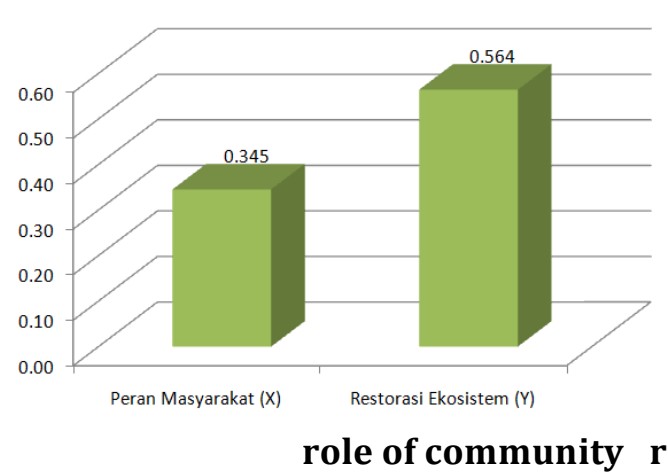

Fig: 5The amount of total exogenous variables influence the integrity of the ecosystem models Malang

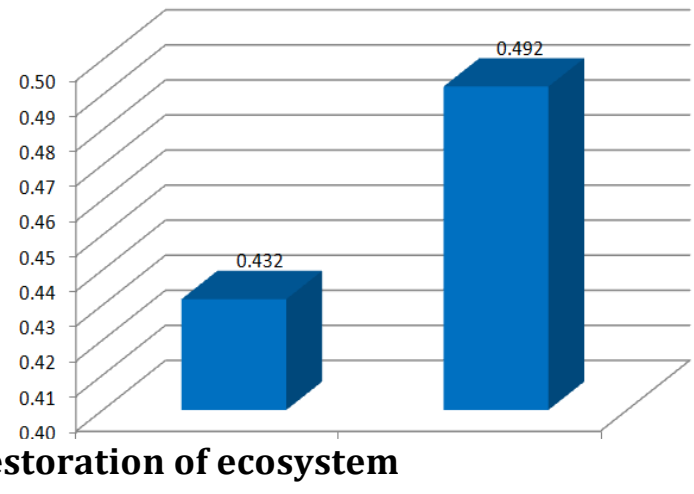

Fig: 6The amount of total exogenous variables influence the integrity of the ecosystem models Gresik

Based on the analysis PLS above, and then prepare a plan for ecosystem restoration of coastal villages. Broadly speaking, the procedure of restoration of coastal ecosystems in the coastal village level include: First, at the planning stage, the head of the village need to form a team first before the process of ecosystem restoration activities carried out. Teams are formed to be composed of elements of village government, representatives of public and private sector representatives. The team needs to be accompanied by a college of elements that act as advisor. After the village head village issued regulations to establish the existence of a team, then the team is equipped with facilities and infrastructure, such as offices and operational funding. Then, the team works with the main focus on restore the mangrove ecosystem as a top priority. The village head gives guidance to the team to conduct ecosystem restoration with the main focus on the mangrove. At this stage the team did an inventory of the baseline data, to decide which location to be restored under supervised by the village head, to develop a work program for five (5) years and to begin restoring the physical condition of the ecosystem, biological aspect, socio-economic conditions of society through empowerment programs. The training to the team should be done by the provincial or local government supervision as well as coming from the university. 
Second, at the implementation phase, the team began working with the team escort and local communities to replant mangrove species. Planting is adjusted to the initial conditions in accordance with the history of the site, before the damage occurs. For that the team must have a history restored the spatial locations at the latest ten years earlier. It is to set targets in the future as the program recovery team work. The team needs to avoid introducing a new species that is different from the old species. The Village heads should encourage the team to be able to complete its work program in accordance with the plan. Therefore, the village head must provide operational funding allocation of funds sourced to the village.

Third, at the stage of monitoring and evaluation, the team must have a tight schedule of when the monitoring should be carried out. This is to keep the mangrove trees that have been planted are not damaged by humans or animals that will pass through the area of restoration. For that the team should have a monitoring task force restoration area equipped with adequate facilities and infrastructure. Every four months, the team has to evaluate the growth of mangrove as the basis to determine if healthy mangrove planted. If the condition mangrove sick, the team should immediately change with new plants. The process must be continually evaluated. Regular meetings within the team and meetings with village leaders and the community should always be carried. Public hearings should be held to listen to the feedback from the community about what the weakness of the workings of the team.

In the phase of monitoring and evaluation, it is done performance assessment, adaptive management and dissemination of results. Performance Assessment related to the monitoring program that will provide immediate feedback on the development of the restoration system according to performance criteria. It is used measurement monitoring parameters including field sampling methods selected for each parameter. Election the appropriate reference or control the precise location around the restoration project is important for the analysis of monitoring data to identify trends that are not related to the project. Adaptive management is monitoring program used as a tool for assessing the success of the project and identify any problems that might affect progress towards the project goals.

Broadly speaking, the options available to the manager is the system maintenance, and modification of project objectives. If the monitoring program to identify deviations from the predicted trajectory of ecosystem development, adjustments can and should do. This kind of adaptive management has been recommended at the national level and is used in many major restoration projects. Dissemination result is important to disseminate information about the project as widely as possible (Hackney, 2000). All aspects of the project must be documented, to show the effects of the decision, and progress toward goals. Planning for future projects require such information to help minimize the costs and maximize the probability of success.

Based on the analysis of Analytical Hierarchy Process (AHP), the key actors to conduct coastal restoration is the village government. This is because the village government is directly adjacent to the village community. If the central government gives authority to the provincial government through the forestry service and rise to marine and fisheries department, the coastal restoration program will not run properly. The village government is a government agency that is closest to the people. It means that the spearhead of local government services. Besides, there are three agencies that have the greatest weight in addition to the village government. They are the Government of Gresik and Malang regency government, followed by the District government, and the office of the environment. To implement 6 (six) factors as proposed by Rudianto (2013), the main focus is to enhance the role of the village government. Increasing the role of the village government is to improve the institutional capacity of the 
public institution supported by the form of community watch groups (Pokmaswas). For the orientation of the role and responsibilities of the village with Pokmaswas government is implementing a restoration program based green economy, poverty eradication, sustainable development, carbon emissions reduction and response to natural disaster preparedness.

Based on the results of questionnaires, the institutional model is based on the principle that: (a) The orientation of the institutional model approach oriented to the restoration of the coastal village six goals, which is the result of interpretative structural modeling. (Rudianto, 2013); (b) To get a description of the village area is more complete, the necessary supporting data are based monograph village profile data and plan rural development strategies; (c) To give authority to the village, the county government gave a letter of assignment to the subdistrict heads to instruct the head of the village create a forum that consists of three stakeholders consisting of representatives of local communities, the private sector and government representatives. Institutional model is using co-management approach. According to Wells, et al (1992) mentioned that all stakeholders were given the opportunity to be actively involved in the management of mangrove forest destruction. This is intended to ensure that the commitment and participation and to accommodate knowledge.

Forum formed to be planned infrastructure in the form of human resources, infrastructure, funding, and support standard operating procedure of the regency government. Forum should implement restoration programs coastal villages and the program is oriented towards poverty alleviation, capacity building, sustainable development, reducing carbon emission and natural disaster preparedness. Institutional model for village restoration can be shown on figure 7 below.

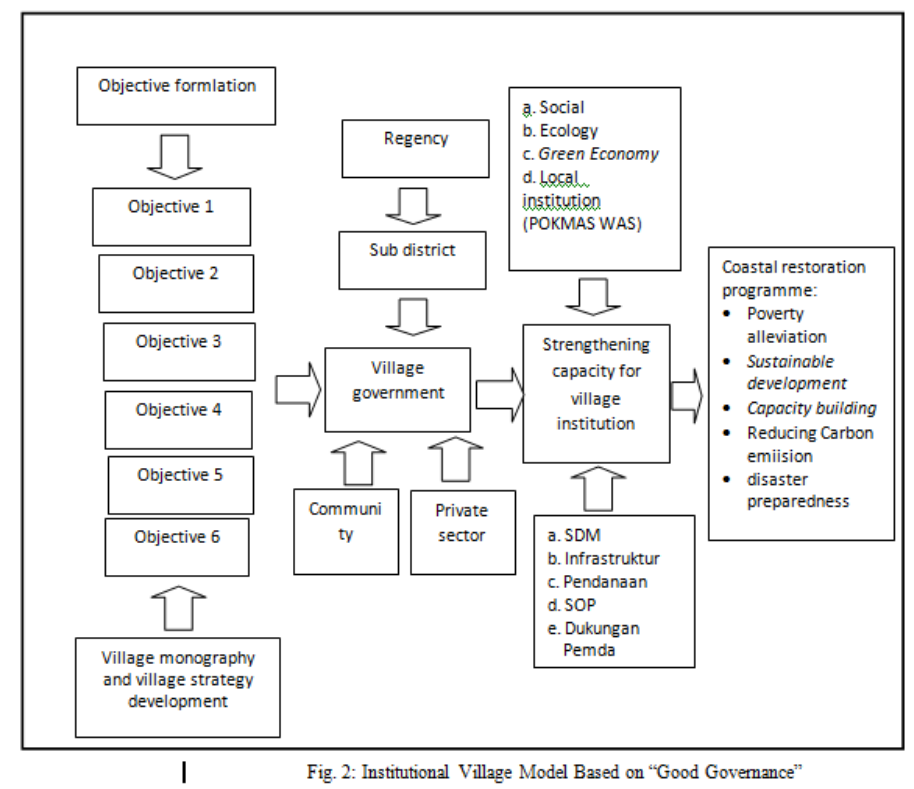

To complete the institutional model of the village government, it needed concept of local regulations proposed to the regents for approval which will be determined by the legislature and the executive. The approval includes the substance of how to regulate: a) the preservation of coastal ecosystems gradual and sustainable community-based; b) increase the sources of financing that comes from both the government and non-government; c) enhance the institutional capacity of both formal and non-formal as well as improving the quality of human resources; d) improving the management of mangrove ecosystems, coral reefs, estuaries as well as sea grass beds; e) enhance the resilience of coastal areas against the threat of natural 
disasters and conflict mitigation in coastal areas; f) improve the competitiveness of coastal areas to increase the added value of products to facilitate fishery products. Therefore the substantive details of the regulations concerning the overall objectives of the program is number of six (6) to complete a short-term coastal damage and problems of medium-term and long-term. Therefore, to establish the basic framework of the development of integrated coastal restoration must have the insight of justice, resilient and highly competitive.

Village heads need to develop village regulations. It required the approval of the head of the village consultative body to be discussed at the village level leaders. After approval, the village head then insert restoration to coastal villages to the medium-term plan of the village. With the enactment of the coastal village restoration plan as part of government policy the village, the village head can conduct restoration activities on the basis of coastal villages to regulations that have been set.

Coastal village restoration plan needs to be integrated into the medium-term rural development plan of the village. The integration should be in conformity with the regulation number 114/2014 ministry of interior. Things that are needed in the integration include: (a) Coastal village restoration plan should be in line with the medium-term development plan of the district; (b) Develop and sorting data about programs and activities that will support the development of the restoration of coastal villages; (c). Grouping restoration programs and activities coastal villages into the field of administration of the village; (d). Format adjustment plan data restoration program with the data format of the village.

Once the integration is complete, the restoration plan followed by the drafting of integrated rural village regulations. Based on the ministry of the interior regulation number 111/2014 regarding the technical guidelines for the village regulation pursuant to paragraph 1 of Article 6 that the regulation of the village must be initiated by the village government. Public hearings should be done so that people can know what will be done collaboration between the government, the public and private sectors. After the completion of public hearings, the head of the Village Consultative Body invited the head of the village to discuss draft regulations coastal village restoration plan. The results of the meeting will be announced to the public.

Based on village regulations on coastal village restoration plan, the structured matrix program for 5 years can be prepared by guidance on table 4 . 
Table 4: Matrix program for coastal village restoration plan

\begin{tabular}{|c|c|c|c|c|c|c|}
\hline \multirow[b]{2}{*}{ No } & \multirow[b]{2}{*}{ Objectives } & \multicolumn{5}{|c|}{$\mathrm{Ye}$ a r } \\
\hline & & 2017 & 2018 & 2019 & 2020 & 2021 \\
\hline 1 & $\begin{array}{l}\text { preservation of } \\
\text { coastal ecosystems } \\
\text { gradual and } \\
\text { sustainable } \\
\text { community-based } \\
\text { Program: }\end{array}$ & $\begin{array}{l}\text { a. the preparation stage } \\
\text { team formation } \\
\text { b. the establishment of } \\
\text { a restoration site } \\
\text { c. preparation of data } \\
\text { base } \\
\text { d. analysis of existing } \\
\text { condirion } \\
\text { e. preparing the } \\
\text { masterplan }\end{array}$ & $\begin{array}{l}\text { a. training program } \\
\text { b. Discussion draft } \\
\text { of coastal } \\
\text { restoration } \\
\text { c. adoption of the } \\
\text { draft restoration } \\
\text { of coastal } \\
\text { villages } \\
\text { d. adoption of the } \\
\text { draft restoration } \\
\text { of coastal } \\
\text { villages }\end{array}$ & $\begin{array}{l}\text { a. } \begin{array}{l}\text { implementation } \\
\text { of the } \\
\text { restoration of } \\
\text { coastal villages }\end{array} \\
\text { b. Identification } \\
\text { of objectives, } \\
\text { restoration } \\
\text { target and } \\
\text { approach } \\
\text { c. Assessment of } \\
\text { vulnerability } \\
\text { d. Monitoring, } \\
\text { review and } \\
\text { revision }\end{array}$ & $\begin{array}{l}\text { a. implementation } \\
\text { of the } \\
\text { restoration of } \\
\text { coastal villages } \\
\text { b. Identification of } \\
\text { objectives, } \\
\text { restoration } \\
\text { target and } \\
\text { approach } \\
\text { c. Assessment of } \\
\text { vulnerability } \\
\text { d. Monitoring, } \\
\text { review and } \\
\text { revision }\end{array}$ & $\begin{array}{ll}\text { a. } & \text { Take } \\
\text { monitoring and } \\
\text { evaluating } \\
\text { b. Feedback } \\
\text { recommendatio } \\
\text { n }\end{array}$ \\
\hline 2 & $\begin{array}{l}\text { Increased sources } \\
\text { of funding both } \\
\text { from government } \\
\text { and non- } \\
\text { government }\end{array}$ & $\begin{array}{l}\text { Preparing and } \\
\text { implementing annual } \\
\text { budget in village } \\
\text { allocation fund } \\
\text { Explore other funding } \\
\text { sources }\end{array}$ & $\begin{array}{l}\text { a. Preparing and } \\
\text { implementing } \\
\text { annual budget in } \\
\text { village } \\
\text { allocation fund } \\
\text { b. Explore other } \\
\text { funding sources } \\
\end{array}$ & $\begin{array}{l}\text { Preparing and } \\
\text { implementing } \\
\text { annual budget in } \\
\text { village allocation } \\
\text { fund } \\
\text { Explore other } \\
\text { funding sources }\end{array}$ & $\begin{array}{l}\text { Preparing and } \\
\text { implementing } \\
\text { annual budget in } \\
\text { village allocation } \\
\text { fund } \\
\text { Explore other } \\
\text { funding sources }\end{array}$ & $\begin{array}{l}\text { Preparing and } \\
\text { implementing } \\
\text { annual budget in } \\
\text { village allocation } \\
\text { fund } \\
\text { Explore other } \\
\text { funding sources }\end{array}$ \\
\hline 3 & $\begin{array}{l}\text { Improving the } \\
\text { institutional } \\
\text { capacity of both } \\
\text { formal and non- } \\
\text { formal as well as } \\
\text { improving human } \\
\text { resources }\end{array}$ & $\begin{array}{l}\text { a. determination and } \\
\text { institutional design } \\
\text { approach } \\
\text { b. election of } \\
\text { representatives in } \\
\text { the forum } \\
\text { c. determination } \\
\text { restoration forum } \\
\text { coastal village with } \\
\text { village heads decree } \\
\text { d. preparation of work } \\
\text { programs forum } \\
\text { e. determination escort } \\
\text { team to the village } \\
\text { head } \\
\text { f. implement } \\
\text { restoration forum }\end{array}$ & $\begin{array}{l}\text { a. reparation of } \\
\text { human resources } \\
\text { development } \\
\text { program } \\
\text { b. business } \\
\text { opportunities, } \\
\text { c. improved } \\
\text { management of } \\
\text { resources and } \\
\text { improvement of } \\
\text { the environment } \\
\text { d. improving } \\
\text { coordination } \\
\text { among forum } \\
\text { e. planning of } \\
\text { infrastructure } \\
\text { necessary }\end{array}$ & $\begin{array}{l}\text { a. establish a work } \\
\text { program } \\
\text { b. business } \\
\text { coaching } \\
\text { c. human } \\
\text { development } \\
\text { d. environmental } \\
\text { development }\end{array}$ & $\begin{array}{l}\text { a. establish a work } \\
\text { program } \\
\text { b. business } \\
\text { coaching } \\
\text { c. human } \\
\text { development } \\
\text { d. environmental } \\
\text { development }\end{array}$ & $\begin{array}{l}\text { a. establish a work } \\
\text { program } \\
\text { b. business } \\
\text { coaching } \\
\text { c. human } \\
\text { development } \\
\text { d. environmental } \\
\text { development }\end{array}$ \\
\hline
\end{tabular}

\section{CONCLUSION}

Institutional model for the implementation of the restoration plan in accordance with the coastal villages of rural communities is a forum which is at the village. The forum consists of representatives of the people elected, representatives of private sector and government representatives appointed by the village headman. Forum works in accordance with the six goals have been determined based on the results of research Rudianto (2014) and the objectives are translated into programs. Coastal village restoration plan is to be implemented in a gradual and sustained. Thus the cooperation between the village government and village consultative bodies should reach an agreement. The deal has been achieved in the form of a decree outlined the village head. After the forum is legal, then draw up a matrix program with duration of five years. The program became the basis matrix operation forum coastal villages to realize the restoration plan.

\section{ACKNOWLEDGMENTS}

The corresponding author are gratefully to thank dean of fisheries and marine science , Brawijaya University to give me opportunity for in depth study for coastal restoration. I also would like to thank Prof. Dr. Ir. Woro Busono, MS whose give me opportunity to conduct this research. 
Rudianto, Susilo, E., \& Supriyatna (2017). Management Ecosystems Restoration Plans for Coastal Villages: Case Study Gresik and Malang Regency, East Java Province, Indonesia. Advances in Social Sciences Research Journal, 4(1) 1-14.

\section{References}

Dahuri, R. et al, (1996) Integrated of Coastal and Marine Resource Management. PT. Pramadya Paramita, Jakarta.

Dahuri, H.R., (2010) Improving the welfare of fishing communities in a sustainable manner. Ocean Magazine, Issue 82. February 2010

Fitriansah, Herry. (2012) Sustainability of Coastal Environmental Management Through Community Empowerment In the Village Kwala Lama, Serdang Begadai. Journal of Regional Development and the City. Publisher University of Diponegoro Planning Bureau, Volume 8 (4) 360-370, December 2012.

Hackney CT. (2000) "Restoration of Coastal Habitats: Expectation and Reality." Battelle Marine Sciences Laboratory, September 30, 2003, page 42 of 54 Ecological Engineering 15(3-4):165.

Nazir, Muhammad, (1988) Research methods, Ghalia Indonesia, Jakarta.

Rudianto, Ismadi, Ade Yamindago. (2013) Integrated Management Strategy to Support MP3EI Ecosystem Restoration: A Case Study of the Coastal Zone, Malang and Gresik, East Java Province. Brawijaya University.

Rudianto, Ismadi, Ade Yamindago. (2014) Restoring Coastal Ecosystems- a case study Malang and Gresik Regency. Journal of Coastal Conservation: Planning and Management. Volume 18, Issue 6, 2014

Rudianto. (2015) Analysis of integrated coastal ecosystem restoration based Co-management: A Case Study In Ujung Pangkah Dan Subdistrict Bungah, Kabupaten Gresik. Research Journal of Life Science. http//rjls.ub.ac.id

Saaty TL.(1986) Decision making for leader, the analytical hierarchy process for decision in complex world. University of Pitsburg.Mervis hall, Pitsburg

Syahyuti. (2003) Surgical Concept of Institutional Strategy Development and Implementation of the Agricultural Research. Socio-Economic Research Center of Agriculture. Penellitian agency Bogor Agricultural Development.

Sugiyono. (2010) Qualitative and Quantitative Research Methods R \& D. Bandung Alfabeta.

Tony, NF dan Utomo BS. (2004) Institutional Development and Social Capital. Subject Module Professional Master of Community Development Department Social sciences Economics Faculty of Agriculture, Bogor.

Wells, M. and Brandon, K. (1992) People and Parks. Linking Protected Area Management with Local Communities. World Bank, WWF-US and US-AID, Washington 